\title{
OPTIMASI PARAMETER MESIN LASER CUTTING TERHADAP KEKASARAN DAN LAJU PEMOTONGAN PADA SUS 316L MENGGUNAKAN TAGUCHI GREY RELATIONAL ANALYSIS METHOD
}

\author{
Rakasita R., Karuniawan B. W., Anda Iviana Juniani ${ }^{*}$ \\ Shipbuilding Institute of Polytechnic Surabaya
}

(Received: February 26, 2016 / Accepted: June 8, 2016)

\begin{abstract}
Abstrak
Optimasi parameter adalah teknik yang digunakan pada proses manufaktur untuk menghasilkan produk terbaik. Penelitian ini bertujuan untuk mengoptimasi parameter CNC laser cutting, yaitu titik fokus sinar laser, tekanan gas cutting dan cutting speed untuk mengurangi variasi terhadap respon kekasaran dan laju pemotongan pada material SUS 316L. Masing-masing parameter memiliki 3 level dan pada penelitian ini menggunakan matriks orthogonal $\mathrm{L}_{9}\left(3^{4}\right)$. Metode ANOVA dan Taguchi digunakan untuk menganalisis data hasil percobaan. Optimasi kekasaran minimum permukaan dan laju pemotongan maksimum pada proses laser cutting dilakukan dengan menggunakan Grey relational analysis. Eksperimen konfirmasi digunakan untuk membuktikan hasil optimal yang telah didapatkan dari metode Taguchi Grey relational analysis. Hasil eksperimen menunjukkan bahwa Taguchi Grey relational analysis efektif digunakan untuk mengoptimasi parameter pemesinan pada laser cutting dengan multi respon.
\end{abstract}

Kata Kunci: kekasaran; laju pemotongan; laser cutting; SUS 316L; taguchi grey relational method

\begin{abstract}
Parameter optimization is used in manufacturing as an indicator to produce the best manufacturing product. This paper studies an optimization parameters of CNC laser cutting such as focus of laser beam, pressure cutting gases and cutting speed for reducing variation of surface roughness and cutting rate on material SUS 316L. Based on $L_{9}\left(3^{4}\right)$ orthogonal array parameters, it is analized using ANOVA based on Taguchi method. In order to optimaze the minimum surface roughness and maximum cutting rate in laser cutting process, it is used Grey relational analysis. The confirmation experiments used to validate the optimal results that has done by Taguchi method. The results show that the Taguchi Grey relational analysis is being effective to optimize the machining parameters for laser cutting process with two responses.
\end{abstract}

Keyword: cutting rate; laser cutting; SUS 316L; roughness; taguchi grey relational analysis

\section{Pendahuluan}

Taguchi menjadi salah satu metode desain eksperimen yang cukup mendunia, karena pertimbangan keefektifan dan keefisienannya (Belavendram, 1995). Sampai saat ini, pengembangan Taguchi masih menjadi topik penelitian yang tetap "hangat" dibicarakan. Modifikasi Taguchi beserta kombinasinya menjadi alternatif-alternatif baru dalam bidang optimasi mesin industri (Hidayat, 2012). Proses optimasi manufaktur, seperti pada turning, welding, injection molding dan proses-proses lainnya, banyak menggunakan metode Taguchi sebagai alat untuk menemukan setting

\footnotetext{
${ }^{*}$ Penulis Korespondensi. email: andahome@gmail.com
}

parameter optimalnya (Akhyar, et al, 2008, Esme, 2009, Rosiawan, 2011). Semakin banyak produk yang dibuat dengan bahan dasar sheet metal mengakibatkan permintaan produksi sheet metal semakin bertambah dan menjadi bermacam-macam, sehingga perlu adanya peningkatkan kualitas produk yang dihasilkan. CNC Laser cutting merupakan salah satu proses pemesinan modern untuk pemotongan sheet metal material keras dengan pola yang rumit dan menghasilkan waktu proses yang relatif cepat. Proses Laser cutting ini diharapkan dapat meningkatkan kualitas produk yang dihasilkan. Salah satu kualitas yang dihasilkan adalah hasil kekasaran permukaan minimum yang diimbangi dengan laju pemotongan yang maksimum.

Proses pemesinan dilakukan pada material SUS 316L dengan menggunakan parameter titik fokus 
sinar laser, tekanan gas cutting dan cutting speed. Metode yang digunakan adalah Taguchi Grey relational analysis. Penggunaan Metode taguchi untuk mengoptimalkan respon kekasaran dan laju pemotongan dikombinasikan dengan menggunakan Grey relational analysis agar didapatkan hasil multi respon yang optimum terhadap kualitas minimum kekasaran dan maksimum laju pemotongan.

\section{Mesin dan Material}

Material yang digunakan adalah jenis SUS 316/316L yaitu austenitik stainless steel bersifat material keras yang memiliki kandungan nikel minimum $8 \%$ sehingga menghasilkan sifat tahan korosi yang cocok digunakan sebagai bahan pembuatan produk biomaterial. Fungsi dari produk biomaterial tersebut digunakan secara langsung oleh manusia sehingga dibutuhkan material yang aman. Komposisi dari material SUS 316L ditunjukkan pada Tabel 1.

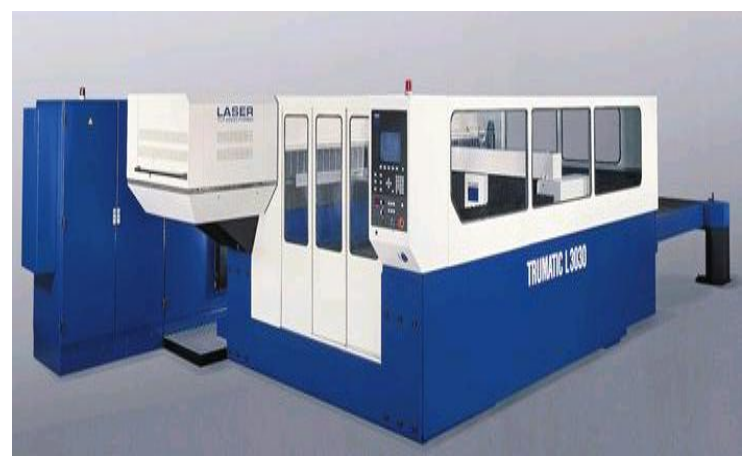

Gambar 1. Mesin CNC Laser cutting Trulaser 3030 (L20)

Mesin yang digunakan adalah mesin CNC Laser cutting Trulaser 3030 (L20) seperti pada Gambar 1 diatas. Fungsinya digunakan untuk memotong material lembaran yang bersifat keras dengan pola rumit dan menghasilkan waktu proses yang cepat. Didalamnya terdapat gas laser dan gas cutting yang digunakan dalam proses pemotongan. Gas laser berfungsi sebagai alat pemotong pada laser cutting dengan cara melelehkan material. Gas laser terdiri dari gas Karbon dioksida $\left(\mathrm{CO}_{2}\right)$, Nitrogen $\left(\mathrm{N}_{2}\right)$ dan Helium (He) dengan komposisi pencampuran $\mathrm{CO}_{2}$ : $\mathrm{N}_{2}$ : He sebagai berikut 1:4.9:16. Sedangkan gas cutting digunakan untuk menghembuskan sisa-sisa lelehan material agar hasil pemotongan lebih bagus. Gas cutting terdiri dari gas Oksigen untuk pemotongan material mild steel dan Nitrogen untuk pemotongan material stainless steel, aluminum dan paduannya. Parameter laser cutting yang mempengaruhi kekasaran dan laju pemotongan adalah titik fokus sinar laser, tekanan gas cutting dan cutting speed. Titik fokus sinar laser merupakan letak ujung sinar laser yang digunakan untuk pemotongan. Tekanan gas cutting digunakan untuk membantu membuang material leleh yang disebabkan sinar laser dalam proses pemotongan. Cutting speed berfungsi untuk mengatur cepat lambat jalannya sinar laser pada saat proses pemotongan.

\section{Metode Taguchi Grey Relational Analysis}

Penggunaan metode ini didasarkan pada jumlah parameter respon yang digunakan yaitu lebih dari satu respon, sehingga metode ini menghasilkan kesimpulan dengan mengotimalkan beberapa parameter respon yang digunakan.

Dasar metodologi yang digunakan adalah metode Taguchi. Metode Taguchi diperkenalkan oleh Dr. Genichi Taguchi (1940) yang merupakan metodologi baru dalam bidang teknik berfungsi menjadikan produk robust terhadap noise. Oleh karena itu sering disebut sebagai Robust Design. Metode Taguchi yang digunakan sebagai dasar, berfungsi untuk menentukan jumlah eksperimen yang akan dilakukan sesuai dengan matriks orthogonal dan nilai rasio S/N. Matriks orthogonal yang digunakan adalah $\mathrm{L}_{9}\left(3^{4}\right)$ dengan derajat bebas 8 . Pemilihan matriks tersebut dikarenakan penggunaan parameter berjumlah 3 dengan level masing-masing berjumlah 3 sehingga membutuhkan derajat bebas minimal 6 . Nilai parameter dan level yang digunakan dalam eksperimen ditunjukkan pada Tabel 2. Maka susunan matriks orthogonal akan menjadi seperti yang ditunjukkan pada Tabel 3 .

Tabel 1. Komposisi SUS 316L (\%)

\begin{tabular}{llllllllll}
\hline Kelas & $\mathrm{C}$ & $\mathrm{Mn}$ & $\mathrm{Si}$ & $\mathrm{P}$ & $\mathrm{S}$ & $\mathrm{Cr}$ & $\mathrm{Mo}$ & $\mathrm{Ni}$ & $\mathrm{N}$ \\
SUS 316L & 0.03 & 2 & 0.75 & 0.045 & 0.03 & 16 & 3 & 14 & 0.1 \\
\hline
\end{tabular}

(Sumber: Inspection certificate SUS 316L ACERINOX, S.A.)

Tabel 2. Nilai Parameter dan Level Eksperimen

\begin{tabular}{lllrrr}
\hline \multicolumn{2}{c}{ Parameter } & Kode & Level 1 & Level 2 & Level 3 \\
\hline Titik focus & $(\mathrm{mm})$ & $\mathrm{A}$ & -14 & -17 & -20 \\
Tek. gas cutting & $(\mathrm{bar})$ & $\mathrm{B}$ & 23 & 20 & 17 \\
Cutting speed & $(\mathrm{m} / \mathrm{menit})$ & $\mathrm{C}$ & 0.6 & 0.4 & 0.2 \\
\hline
\end{tabular}


Tabel 3. Matriks Orthogonal $\mathrm{L}_{9}\left(3^{4}\right)$

\begin{tabular}{ccccc}
\hline \multirow{2}{*}{ Eksperimen } & \multicolumn{4}{c}{$\mathrm{L}_{9}\left(3^{4}\right)$} \\
\cline { 2 - 5 } & Titik Fokus & Tek. Gas Cutting & Cutting Speed & Error \\
\hline 1 & $-14 \mathrm{~mm}$ & $23 \mathrm{bar}$ & $0.6 \mathrm{~m} / \mathrm{menit}$ & 0 \\
2 & $-14 \mathrm{~mm}$ & $20 \mathrm{bar}$ & $0.4 \mathrm{~m} / \mathrm{menit}$ & 0 \\
3 & $-14 \mathrm{~mm}$ & $17 \mathrm{bar}$ & $0.2 \mathrm{~m} / \mathrm{menit}$ & 0 \\
4 & $-17 \mathrm{~mm}$ & $23 \mathrm{bar}$ & $0.4 \mathrm{~m} / \mathrm{menit}$ & 0 \\
5 & $-17 \mathrm{~mm}$ & $20 \mathrm{bar}$ & $0.2 \mathrm{~m} / \mathrm{menit}$ & 0 \\
6 & $-17 \mathrm{~mm}$ & $17 \mathrm{bar}$ & $0.6 \mathrm{~m} / \mathrm{menit}$ & 0 \\
7 & $-20 \mathrm{~mm}$ & $23 \mathrm{bar}$ & $0.2 \mathrm{~m} /$ menit & 0 \\
8 & $-20 \mathrm{~mm}$ & $20 \mathrm{bar}$ & $0.6 \mathrm{~m} /$ menit & 0 \\
9 & $-20 \mathrm{~mm}$ & $17 \mathrm{bar}$ & $0.4 \mathrm{~m} /$ menit & 0 \\
\hline
\end{tabular}

Metode Taguchi juga digunakan untuk menentukan nilai optimal pada setiap respon yang diinginkan dengan mencari nilai rasio $\mathrm{S} / \mathrm{N}$ pada masing-masing respon sesuai karakteristik yang diamati yaitu semakin kecil semakin baik untuk respon kekasaran permukaan dan semakin besar semakin baik untuk respon laju pemotongan (4 dan 5).

Kemudian proses perhitungan dilakukan dengan menggunakan metode Grey Relational Analysis (GRA) sehingga didapatkan pengoptimalan lebih dari satu respon berdasarkan nilai rasio S/N yang didapat pada metode Taguchi sebelumnya. Perhitungan data awal dalam metode Grey Relational Analysis yaitu normalisasi rasio $\mathrm{S} / \mathrm{N}$ untuk pengolahan data dengan mengubah urutan asli (rasio $\mathrm{S} / \mathrm{N}$ Taguchi) menjadi urutan yang sebanding pada metode analisis Grey. Normalisasi rasio $\mathrm{S} / \mathrm{N}$ digunakan untuk menyeimbangkan antara nilai rasio $\mathrm{S} / \mathrm{N}$ Taguchi dengan Grey relational analysis (6). Selanjutnya adalah Grey relational coeeficient (7) yaitu nilai koefisien dari metode Grey dengan nilai diantara 0 dan 1 untuk setiap respon yang diamati. Kemudian dilakukan penggabungan dari respon yang diamati dengan pengolahan data berupa nilai Grey relational grade (9). Pada Grey relational grade menggunakan sistem pembobotan pada respon yang digunakan. Pembobotan yang digunakan dalam penelitian harus sama dengan 1 atau $100 \%$. Kombinasi optimal dihasilkan dari nilai Grey relational grade tertinggi kemudian hasil yang didapatkan dianalisa dengan perhitungan ANOVA. Perhitungan ANOVA digunakan untuk mengetahui kombinasi parameter yang terbaik dalam eksperimen.

\section{Kekasaran}

Kekasaran merupakan salah satu karakteristik kualitas yang dihasilkan oleh sebuah produk. Oleh karena itu dalam memilih proses pengerjaan aspek kekasaran permukaan perlu dipertimbangkan (Rochim, T., 2001).

Penyimpangan rata-rata aritmatika $(\mathrm{Ra})$ adalah nilai rata-rata dari ordinat profil efektif garis rataratanya. Profil efektif adalah garis bentuk dari potongan permukaan efektif pada sebuah bidang terhadap permukaan geometris ideal. Penjelasan mengenai permukaan geometris, permukaan efektif, profil geometris dan profil efektif ditunjukkan pada Gambar 2

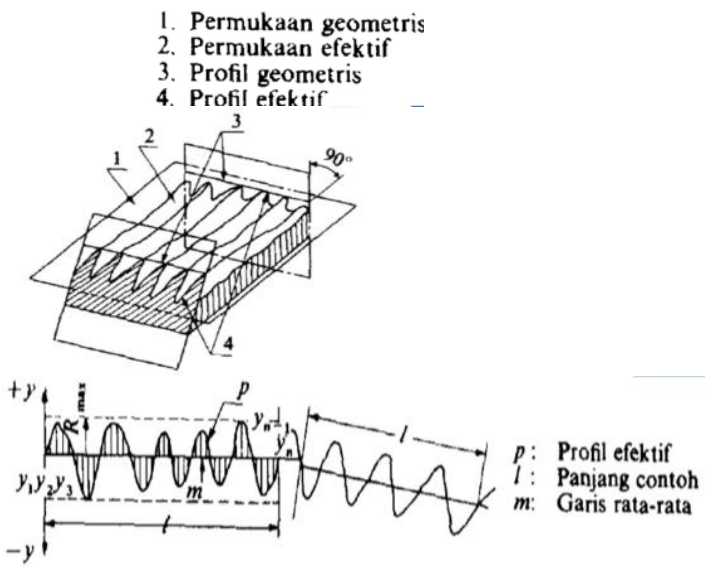

Gambar 2. Penyimpangan rata-rata

(Sumber: Sato, G. T. dan Sugiarto, N. H., 1994)

Rochim, T. (2001) mendefinisikan bahwa yang paling banyak digunakan untuk mengidentifikasi kekasaran permukaan adalah parameter Ra. Untuk memeriksa kualitas permukaan akhir benda kerja yang dihasilkan dalam jumlah banyak cocok digunakan parameter $\mathrm{Ra}$ dikarenakan penggunaan parameter Ra lebih peka jika terjadi penyimpangan pada proses pemesinan dibandingkan dengan parameter-parameter kekasaran permukaan yang lain.

Pengujian kekasaran yang dilakukan pada eksperimen ini dengan menggunakan pengujian $\mathrm{Ra}$ (penyimpangan aritmatika) yaitu dengan alat uji kekasaran permukaan merk Mitutoyo SJ 201. Pengukuran kekasaran permukaan dilakukan disetiap sisi pemotongan dengan arah horisontal. Pengukuran dilakukan 4 kali yaitu pertama dilakukan pada sisi satu yang berada diatas, sisi dua yang berada dibawah dan dua sisi berikutnya berada ditengah benda kerja. Dari pengukuran kekasaran tersebut didapatkan nilai rata-rata hasil kualitas kekasaran permukaan pemotongan. Langkah selanjutnya didapatkan nilai 
rata-rata kekasaran permukaan yang nantinya digunakan sebagai nilai terhadap respon kekasaran. Arah dan bentuk pengujian kekasaran dapat dilihat pada Gambar 3 berikut.

Arah goresan

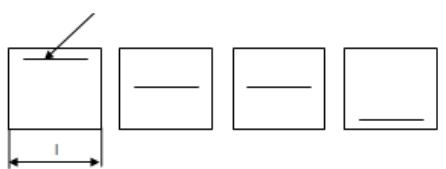

Gambar 3. Pengukuran Kekasaran Permukaan Laju Pemotongan (Material Removal Rate)

Nilai kekasaran yang dicari akan mempengaruhi nilai laju pemotongan. Laju pemotongan yang tidak tepat akan menghasilkan produk yang kurang baik. Laju pemotongan (MRR) pada mesin CNC laser cutting merupakan fungsi dari sinar laser dalam melelehkan material saat proses pemotongan. Pada mesin CNC laser cutting laju pemotongan didapatkan berdasarkan banyaknya material yang terbuang atau leleh (slag) dalam satuan waktu. Untuk mencari banyaknya material yang terbuang didapat dari fungsi pengurangan antara volume sisa dari produk dengan volume produk yang didapat per satuan waktu (waktu aktual pengerjaan). Rancangan bentuk pemotongan yang dilakukan pada penelitian ini ditunjukkan pada Gambar 4 dan hasil pemotongan yang diperoleh dari mesin CNC laser cutting ditunjukkan pada Gambar 5.

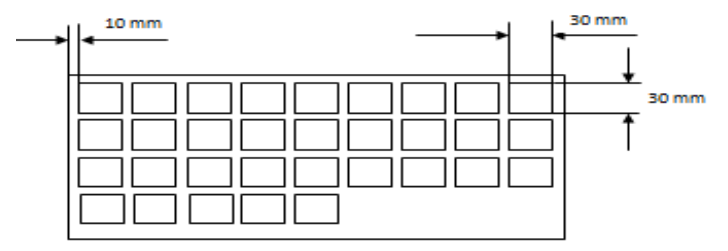

Gambar 4. Layout eksperimen

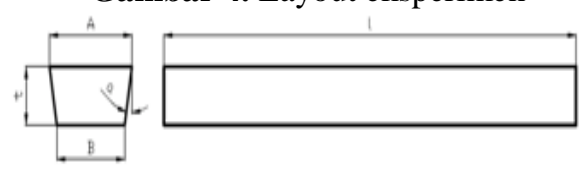

Gambar 5. Hasil Pemotongan

Rumus yang digunakan untuk menentukan nilai laju pemotongan adalah sebagai berikut:

$\mathrm{MRR}=\mathrm{v} \times \mathrm{L} \quad$ (Persamaan 1$)$

Dimana:

$\mathrm{V}=$ Kecepatan potong $(\mathrm{mm} / \mathrm{min})$

$\mathrm{L}=$ Luas penampang $\left(\mathrm{mm}^{2}\right)$ Untuk Luas penampang hasil pemotongan dapat dihitung berdasarkan persamaan berikut:
Luas $=\frac{a+b}{2} \quad$ (Persamaan 2)

Dimana:

$\mathrm{a}=$ panjang sisi atas $(\mathrm{mm})$

$\mathrm{b}=$ panjang sisi bawah $(\mathrm{mm})$

$\mathrm{t}=$ tebal material $/$ tinggi $(\mathrm{mm})$

\section{Hasil Dan Pembahasan}

Penelitian ini menggunakan material SUS 316L dengan tebal $10 \mathrm{~mm}$. Parameter yang digunakan dalam penelitian ini adalah parameter titik fokus sinar laser dengan nilai $-14 \mathrm{~mm} ;-17 \mathrm{~mm}$ dan $-20 \mathrm{~mm}$, parameter tekanan gas cutting dengan nilai 23 bar; 20 bar dan 17 bar dan parameter cutting speed dengan nilai $0.6 \mathrm{~m} /$ menit; $0.4 \mathrm{~m} /$ menit dan $0.2 \mathrm{~m} /$ menit. Proses pemotongan menggunakan mesin CNC laser cutting TruLaser 3030 L20 milik PT. Dempo Laser Metalindo dengan bentuk pemotongannnya berdimensi 30x30 mm.

Proses mengoptimalkan parameter menggunakan metode Taguchi Grey relational analysis. Jumlah eksperimen adalah 9 dan dilakukan 3 kali replikasi untuk proses penelitian berdasarkan metode Taguchi. Lalu dilakukan proses optimasi terhadap multi respon menggunakan metode Grey relational analysis. Dalam proses pengambilan data yang dilakukan adalah mengukur waktu aktual dengan stopwatch dan mengukur hasil dimensi dari hasil produk penelitian, yang kemudian dijadikan sebagai input data pada respon laju pemotongan. Kemudian dilakukan uji kekasaran permukaan pada hasil kualitas pemotongan sehingga nilai kekasaran permukaan digunakan sebagai input data pada respon kekasaran. Karakteristik yang dimiliki masingmasing respon adalah karakteristik semakin kecil semakin baik untuk respon kekasaran permukaan dan semakin besar semakin baik untuk respon laju pemotongan.

\section{Hasil Penelitian}

Penelitian ini menggunakan matriks orthogonal $\mathrm{L}_{9}\left(3^{4}\right)$ sehingga terdapat 9 eksperimen dengan 3 kali replikasi. Nilai rata-rata digunakan sebagai nilai awal pada masing-masing respon. Untuk nilai respon kekasaran dilakukan dengan pengujian $\mathrm{Ra}$ menggunakan alat surface roughness tester dengan satuan $\mu \mathrm{m}$. Sedangkan nilai laju pemotongan didapatkan dari Persamaan 1 dan 2. Dari hasil eksperimen didapatkan nilai rata-rata kekasaran permukaan dan laju pemotongan setiap eksperimen seperti ditunjukkan pada Tabel 4 .

Tabel 4.Hasil Pengukuran dan Pengolahan Data Respon

\begin{tabular}{|c|c|c|c|c|c|}
\hline \multirow{2}{*}{ No. } & \multicolumn{3}{|c|}{ Kombinasi Parameter } & \multirow{2}{*}{$\begin{array}{c}\text { Kekasaran } \\
(\mu \mathrm{m})\end{array}$} & \multirow{2}{*}{$\begin{array}{c}\text { MRR } \\
\left(\mathrm{mm}^{3} / \mathrm{min}\right)\end{array}$} \\
\hline & $\mathrm{A}(\mathrm{mm})$ & B (bar) & $\mathrm{C}(\mathrm{m} / \mathrm{menit})$ & & \\
\hline 1 & -14 & 23 & 0.6 & 5.0283 & 30.5109 \\
\hline
\end{tabular}




\begin{tabular}{llllll}
\hline 2 & -14 & 20 & 0.4 & 3.4225 & 19.0797 \\
3 & -14 & 17 & 0.2 & 2.8983 & 14.8248 \\
4 & -17 & 23 & 0.4 & 7.5767 & 25.0768 \\
5 & -17 & 20 & 0.2 & 3.9342 & 17.5270 \\
6 & -17 & 17 & 0.6 & 4.4183 & 39.3372 \\
7 & -20 & 23 & 0.2 & 9.5058 & 18.4785 \\
8 & -20 & 20 & 0.6 & 10.3592 & 25.1417 \\
9 & -20 & 17 & 0.4 & 4.2583 & 29.7569 \\
\hline
\end{tabular}

Tabel 5. Nilai Rasio S/N

\begin{tabular}{|c|c|c|c|c|c|}
\hline \multirow{2}{*}{ No. } & \multicolumn{3}{|c|}{ Kombinasi Parameter } & Kekasaran & MRR \\
\hline & $\mathrm{A}(\mathrm{mm})$ & B (bar) & $\mathrm{C}(\mathrm{m} / \mathrm{menit})$ & Rasio S/N & Rasio S/N \\
\hline 1 & -14 & 23 & 0.6 & -14.0285 & 29.3651 \\
\hline 2 & -14 & 20 & 0.4 & -10.6869 & 23.8372 \\
\hline 3 & -14 & 17 & 0.2 & -9.2430 & 23.3754 \\
\hline 4 & -17 & 23 & 0.4 & -17.5896 & 27.1349 \\
\hline 5 & -17 & 20 & 0.2 & -11.8971 & 23.8275 \\
\hline 6 & -17 & 17 & 0.6 & -12.9052 & 31.6180 \\
\hline 7 & -20 & 23 & 0.2 & -19.5598 & 25.2831 \\
\hline 8 & -20 & 20 & 0.6 & -20.3065 & 27.7223 \\
\hline 9 & -20 & 17 & 0.4 & -12.5848 & 28.7935 \\
\hline
\end{tabular}

\section{Perhitungan Metode Taguchi}

Setelah mendapatkan hasil pengukuran dan pengolahan data untuk masing-masing respon maka dilakukan perhitungan dengan metode Taguchi. Metode Taguchi digunakan untuk mendapatkan nilai yang optimal pada masing-masing respon dengan menggunakan perhitungan rasio $\mathrm{S} / \mathrm{N}$ Taguchi sesuai dengan karateristik respon yang digunakan. Perhitungan rasio $\mathrm{S} / \mathrm{N}$ berdasarkan karakteristik respon dijabarkan dalam perumusan berikut:

a. Semakin kecil semakin baik untuk respon kekasaran permukaan.

$\mathrm{S} / \mathrm{N} \geq 0$ sehingga nilai $\mathrm{S} / \mathrm{N}$ mendekati nol $(\mathrm{S} / \mathrm{N} \rightarrow$ 0)

$$
S / N=-10 \log \left(\frac{1}{n} \sum_{i=1}^{r} \frac{1}{Y_{i}^{2}}\right) \text { (Persamaan 3) }
$$

Dimana:

$\mathrm{n}=$ jumlah pengulangan dari suatu eksperimen

$\mathrm{Y}=$ data yang diperoleh dari percobaan

b. Semakin besar semakin baik (MRR) untuk respon laju pemotongan $0<\mathrm{S} / \mathrm{N}<\infty$

$$
S / N=-10 \log \left(\frac{1}{n} \sum_{i=1}^{r} Y_{i}^{2}\right)_{(\text {Persamaan 4) }}
$$

Dimana:

$\mathrm{n}=$ jumlah pengulangan dari suatu eksperimen

$\mathrm{Y}=$ data yang diperoleh dari percobaan

Hasil perhitungan rasio S/N Taguchi untuk masing-masing respon ditunjukkan seperti pada Tabel 5.
Optimasi dengan Metode Grey Relational Analysis (GRA)

STEP 1: Perhitungan normalisasi rasio $\mathrm{S} / \mathrm{N}$ secara umum menggunakan persamaan berikut:

$$
\mathrm{Xi} *(\mathrm{k})=\frac{\mathrm{Xo}^{\circ}(\mathrm{k})-\operatorname{Min} \mathrm{Xo}^{\circ}(\mathrm{k})}{\operatorname{Max} \mathrm{Xo}^{\circ}(\mathrm{k})-\operatorname{Min} \mathrm{Xo}^{\circ}(\mathrm{k})}(\text { Persamaan 5) }
$$

dimana Max Xo (k) adalah maksimum nilai dari himpunan $\mathrm{k}$ dan Min Xo (k) adalah nilai minimum dari himpunan $\mathrm{k}$.

STEP 2: Perhitungan deviasi sebagai berikut: $\Delta O i(k)=|X o *(k)-X i *(k)|$ (Persamaan 6)

$\Delta O i(k)$ adalah nilai absolut perbedaan antara Xo $(\mathrm{k})$ dan Xi (k) yaitu selisih secara absolut dari data awal dengan data yang telah dinormalisasi.

STEP 3: Perhitungan Grey relational coeeficient menggunakan persamaan berikut:

$\gamma(X o(k), X i(k))=\frac{\Delta \min +\zeta \Delta \max }{\Delta o i(k)+\zeta \Delta \max }($ Persamaan 7$)$

dimana:

$$
\begin{aligned}
& \Delta_{\min }=\min _{\mathrm{i}} \min _{k} \Delta_{0, i}(k) \\
& \Delta_{\max }=\max _{\mathrm{i}} \max _{k} \Delta_{0, i}(k) \\
& \zeta \quad=\text { distinguish coefficient } .
\end{aligned}
$$

Pada umumnya nilai distinguish coefficient diatur berdasarkan kebutuhan dan nilainya berada antara 0 dan 1.

Nilai yang dihasilkan dari metode Grey Relational Analysis untuk respon kekasaran ditunjukkan pada Tabel 6 dan respon laju pemotongan ditunjukkan pada Tabel 7. 
Tabel 6. Nilai Grey Relational Respon Kekasaran

\begin{tabular}{|c|c|c|c|c|c|c|}
\hline \multirow{2}{*}{ No. } & \multicolumn{3}{|c|}{ Kombinasi Parameter } & \multirow{2}{*}{$\begin{array}{c}\text { Normalisasi } \\
\mathrm{Xi}(2)\end{array}$} & \multirow{2}{*}{$\begin{array}{r}\text { Deviasi } \\
\Delta \text { oi }(2)\end{array}$} & \multirow[t]{2}{*}{ GRC } \\
\hline & $\mathrm{A}(\mathrm{mm})$ & B (bar) & $\mathrm{C}(\mathrm{m} / \mathrm{min})$ & & & \\
\hline 1 & -14 & 23 & 0.6 & 0.5675 & 0.4325 & 0.5362 \\
\hline 2 & -14 & 20 & 0.4 & 0.8695 & 0.1305 & 0.7930 \\
\hline 3 & -14 & 17 & 0.2 & 1.0000 & 0.0000 & 1.0000 \\
\hline 4 & -17 & 23 & 0.4 & 0.2456 & 0.7544 & 0.3986 \\
\hline 5 & -17 & 20 & 0.2 & 0.7601 & 0.2399 & 0.6758 \\
\hline 6 & -17 & 17 & 0.6 & 0.6690 & 0.3310 & 0.6017 \\
\hline 7 & -20 & 23 & 0.2 & 0.0675 & 0.9325 & 0.3490 \\
\hline 8 & -20 & 20 & 0.6 & 0.0000 & 1.0000 & 0.3333 \\
\hline 9 & -20 & 17 & 0.4 & 0.6979 & 0.3021 & 0.6234 \\
\hline
\end{tabular}

Tabel 7. Nilai Grey Relational Respon Laju Pemotongan

\begin{tabular}{ccccccc}
\hline \multirow{2}{*}{ No. } & \multicolumn{3}{c}{ Kombinasi Parameter } & Normalisasi & Deviasi & GRC \\
\cline { 2 - 6 } & A (mm) & B (bar) & C (m/min) & Xi (1) & $\Delta$ oi (1) & \\
\hline 1 & -14 & 23 & 0.6 & 0.7267 & 0.2733 & 0.6466 \\
2 & -14 & 20 & 0.4 & 0.056 & 0.944 & 0.3463 \\
3 & -14 & 17 & 0.2 & 0.0000 & 1.0000 & 0.3333 \\
4 & -17 & 23 & 0.4 & 0.4561 & 0.5439 & 0.479 \\
5 & -17 & 20 & 0.2 & 0.0548 & 0.9452 & 0.346 \\
6 & -17 & 17 & 0.6 & 1.0000 & 0.0000 & 1.0000 \\
7 & -20 & 23 & 0.2 & 0.2314 & 0.7686 & 0.3941 \\
8 & -20 & 20 & 0.6 & 0.5274 & 0.4726 & 0.5141 \\
9 & -20 & 17 & 0.4 & 0.6573 & 0.3427 & 0.5933 \\
\hline
\end{tabular}

Tabel 8. Hasil Nilai Grey Relational Grade (GRG)

\begin{tabular}{ccccc}
\hline $\begin{array}{c}\text { No. } \\
\text { Eksperimen }\end{array}$ & $\begin{array}{c}0.6 \\
\text { GRC }\end{array}$ & $\begin{array}{c}0.4 \\
\text { GRC } \\
\text { Kekasaran }\end{array}$ & $\begin{array}{c}\text { GRG } \\
\text { MRR }\end{array}$ & Ranking \\
1 & 0.3217 & 0.2586 & $\left(\mathrm{Y}_{3}\right)$ & \\
2 & 0.4758 & 0.1385 & 0.5803 & 5 \\
3 & 0.6000 & 0.1333 & 0.6143 & 3 \\
4 & 0.2392 & 0.1916 & 0.7333 & 2 \\
5 & 0.4055 & 0.1384 & 0.4307 & 7 \\
6 & 0.3610 & 0.4000 & 0.5439 & 6 \\
7 & 0.2094 & 0.1577 & 0.7610 & 1 \\
8 & 0.2000 & 0.2056 & 0.3671 & 9 \\
9 & 0.3740 & 0.2373 & 0.4056 & 8 \\
\hline
\end{tabular}

Analysis of Variance for SN ratios

$\begin{array}{lrrrrrr}\text { Source } & \text { DF } & \text { Seg SS } & \text { Adj SS } & \text { Adj MS } & \text { F } & \text { P } \\ \text { A } & 2 & 14.3446 & 14.3446 & 7.1723 & 6.41 & 0.135 \\ \text { B } & 2 & 22.8788 & 22.8788 & 11.4394 & 10.23 & 0.089 \\ \text { C } & 2 & 0.5120 & 0.5120 & 0.2560 & 0.23 & 0.814 \\ \text { Residual Error } & 2 & 2.2361 & 2.2361 & 1.1181 & & \\ \text { Total } & & 8 & 39.9715 & & & \end{array}$

Gambar 6. Tabel ANOVA

Response Table for Signal to Noise Ratios Larger is better

$\begin{array}{lrrr}\text { Level } & \text { A } & \text { B } & \text { C } \\ 1 & -3.884 & -6.916 & -4.979 \\ 2 & -4.993 & -5.787 & -5.274 \\ 3 & -6.939 & -3.113 & -5.563 \\ \text { Delta } & 3.054 & 3.802 & 0.584 \\ \text { Rank } & 2 & 1 & 3\end{array}$

Gambar 7. Nilai Respon Rasio S/N 


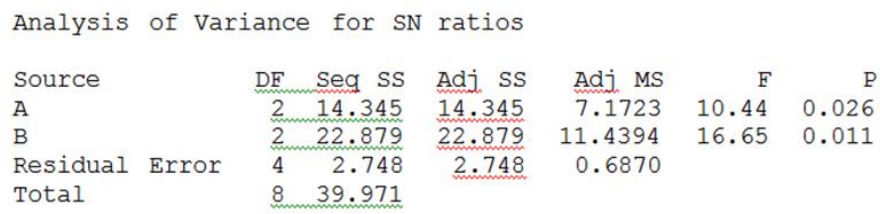

Gambar 8. Tabel ANOVA (setelah Polling Up parameter C)

STEP 4: Perhitungan Grey relational grade menggunakan persamaan berikut:

$\gamma(X o, X i)=\frac{1}{m} \sum_{i=1}^{m} \gamma(\mathrm{Xo}(\mathrm{k}), \mathrm{Xi}(\mathrm{k}))$

dimana:

(Persamaan 8)

$\mathrm{m}=$ jumlah dari respon

Pembobotan yang digunakan pada penelitian ini adalah 0.6 untuk respon kekasaran permukaan dan 0.4 untuk respon laju pemotongan. Karakteristik kualitas utama dari produk biomaterial adalah nilai kekasaran permukaan minimum dan disertai dengan laju pemotongan maksimum, sehingga hasil produk berkualitas baik dan efisien terhadap waktu. Dari eksperimen ini dihasilkan nilai optimasi multi respon yang diamati seperti ditunjukkan pada Tabel 8 .

Dari Tabel 8. Hasil Grey relational grade yang telah didapatkan maka dapat ditarik kesimpulan bahwa nilai Grey relational grade yang optimum adalah eksperimen yang memiliki nilai kombinasi parameter dengan level yang terbaik. Nilai total Grey relational grade yang optimum adalah sebesar 0.7610 pada eksperimen 6 . Sehingga eksperimen 6 dengan kombinasi level parameter $\mathrm{A}_{2} \mathrm{~B}_{3} \mathrm{C}_{1}$ (yaitu pada titik fokus sinar laser dengan nilai $-17 \mathrm{~mm}$, tekanan gas cutting pada nilai 17 bar dan cutting speed pada nilai $0.6 \mathrm{~m} / \mathrm{menit}$ ) adalah kombinasi parameter dengan level yang terbaik penelitian ini.

\section{ANOVA}

Setelah mendapatkan eksperimen dengan nilai Grey relational grade yang optimum, maka dibutuhkan perhitungan untuk menganalisis respon parameter dengan level yang memiliki konstribusi paling optimum terhadap respon yang diteliti. Hal ini dilakukan analisis menggunakan ANOVA dalam metode Taguchi. ANOVA dilakukan dengan menggunakan software Minitab. Input data yang digunakan dalam perhitungan ANOVA adalah nilai rasio S/N yang dimiliki oleh GRG dengan persamaan 4. Sehingga didapatkan output data pada Gambar 6 dan Gambar 7.

Pada Gambar 6 ditunjukkan bahwa nilai $\mathrm{F}$ hitung yang dihasilkan parameter $\mathrm{C}$ kurang dari nilai $\mathrm{F}$ tabel yaitu 6.39 sehingga parameter $\mathrm{C}$ perlu dilakukan pooling up. Pooling up dilakukan dengan tujuan untuk mengestimasi variansi error pada ANOVA, sehingga estimasi yang dihasilkan semakin baik. Hasil perhitungan setelah parameter $\mathrm{C}$ dilakukan pooling up ditunjukkan pada Gambar 8.
Selanjutnya sebagai input data yang digunakan adalah data setelah dilakukan pooling up yaitu yang ditunjukkan pada Gambar 8.

Berdasarkan hasil pengolahan software minitab yang ditunjukkan pada Gambar 6 menyatakan bahwa parameter tekanan gas cutting (B) memiliki nilai $\mathrm{F}$ hitung tertinggi yaitu sebesar 10.23 sehingga parameter tekanan gas cutting (B) adalah parameter yang paling mempengaruhi pada penelitian ini. Pada Gambar 7 dapat diambil kesimpulan bahwa rangking 1 merupakan nilai parameter yang paling mempengaruhi penelitian sehingga parameter gas cutting (B) adalah parameter yang paling berpengaruh. Selanjutnya diikuti dengan parameter titik fokus sinar laser (A) dan terakhir parameter cutting speed (C). Pada Gambar 7 dapat dilihat bahwa kombinasi parameter level yang paling optimum terletak pada kombinasi level parameter $\mathrm{A}_{1} \mathrm{~B}_{3} \mathrm{C}_{1}$ yaitu pada titik fokus sinar laser dengan nilai -14 mm, tekanan gas cutting pada nilai 17 bar dan cutting speed pada nilai $0.6 \mathrm{~m} / \mathrm{menit}$ yang menghasilkan respon kekasaran permukaan minimum dan laju pemotongan maksimum.

\section{Interpretasi Hasil Eksperimen}

Interpretasi hasil eksperimen yang dilakukan pada metode Taguchi menggunakan ANOVA adalah sebagai berikut:

\section{Persen konstribusi}

Persen konstribusi digunakan untuk mengetahui besarnya konstribusi yang diberikan oleh masingmasing parameter yang digunakan pada eksperimen. Untuk menentukan besarnya persen konstribusi terlebih dahulu melakukan perhitungan SS' untuk parameter A (titik fokus sinar laser) dan B (tekanan gas cutting). Input data yang digunakan adalah sum of square untuk masing-masing parameter $\left(\mathrm{SS}_{\mathrm{A} 3}\right.$ dan $\left.\mathrm{SS}_{\mathrm{B} 3}\right)$, derajat bebas untuk masing-masing parameter $\left(\mathrm{V}_{\mathrm{A}}\right)$ dan mean of square error pada respon gabungan yang telah ditunjukkan pada Tabel 4.15. Perumusan yang digunakan adalah sebagai berikut:

$$
\begin{aligned}
\mathrm{SS}^{\prime}{ }_{\mathrm{A} 3} & =\mathrm{SS}_{\mathrm{A} 3}-\mathrm{MS}_{\mathrm{e} 3}\left(\mathrm{~V}_{\mathrm{A}}\right) \\
& =14.3446-0.6870(2)=11.5965
\end{aligned}
$$

$\mathrm{SS}^{\prime}{ }_{\mathrm{B} 3}=20.1307$

$\mathrm{SS}{ }_{\text {total } 3}=11.5965+20.1307=31.7272$

SS' yang telah didapatkan sebelumnya akan digunakan sebagai input data pada perhitungan persen konstribusi untuk masing-masing parameter. Kemudian dibutuhkan data sum of 
square total $\left(\mathrm{SS}_{\text {total3 }}\right)$ pada respon gabungan yang ditunjukkan pada tabel 4.15. Perhitungan persen kostribusi didapatkan dari rumus seperti berikut:

$$
\begin{aligned}
\rho_{\mathrm{A}} & =\frac{\mathrm{SS}_{\mathrm{A}}}{\mathrm{SS}_{\text {total }}} \times 100 \% \\
\rho_{\mathrm{A}} & =\frac{11.5965}{39.9715} \times 100 \%=29.0119 \% \\
\rho_{\mathrm{B}} & =50.3626 \% \\
\rho_{\mathrm{e}} & =100 \%-(29.0119 \%+50.3626 \%) \\
& =20.6255 \%
\end{aligned}
$$

Persentase konstribusi error $\geq 15 \%$ artinya ada parameter yang terabaikan dalam penelitian. Tetapi persentase konstribusi error $\leq 50 \%$ artinya error tidak terlalu besar sehingga penelitian dapat dilanjutkan (Soejanto, I., 2009).

Hal ini dapat disimpulkan bahwa konstribusi yang terdapat pada masing-masing parameter dalam mengurangi variasi dari respon kekasaran dan laju pemotongan adalah sebagai berikut:

1. Parameter yang memiliki konstribusi terbesar adalah parameter B (tekanan gas cutting) dengan nilai persen kostribusi $50.3626 \%$ dalam mengurangi variasi dari respon kekasaran permukaan dan laju pemotongan.

2. Parameter berikutnya yang memiliki konstribusi dalam mengurangi variasi dari respon kekasaran permukaan dan laju pemotongan adalah parameter A (titik fokus sinar laser) dengan nilai persen konstribusi $29.0119 \%$

3. Sedangkan parameter C (cutting speed) tidak memiliki konstribusi yang signifikan dalam mengurangi variasi dari respon kekasaran dan laju pemotongan.

\section{Interval Kepercayaan}

Digunakan untuk menentukan interval nilai toleransi yang mampu dicapai pada eksperimen dengan kombinasi level parameter yang optimum. Interval kepercayan rata-rata pada tingkat kepercayaan $95 \%$ didapat dari perumusan berikut ini: Diketahui F0.05 $(1 ; 4)=7.71$

$\mathrm{MSe}=0.6870$

$$
\begin{aligned}
& n_{\text {kff }}=\frac{\text { Jumlah total eksperimen }}{1+\text { jumlah derajat kebebasamperkiraan rata }- \text { rata }} \\
& n_{\text {eff }}=\frac{9 \times 3}{1+(2+2)}=5.4 \\
& C l= \pm \sqrt{F_{(0.05,4,4)} \times M S_{e} \times \frac{1}{n_{e f f}}} \\
& = \pm 0.9904 \\
& = \pm \sqrt{7.71 \times 0.6870 \times \frac{1}{5.4}} \\
& \mu_{\text {prediksi }}-\mathrm{Cl} \leq \mu_{\text {predikgi }} \leq \mu_{\text {prediksi }}+\mathrm{Cl} \\
& -1.7257-0.9904 \leq \mu_{\text {predikisi }} \leq \quad-1.7257+ \\
& 0.9904 \\
& -2.7162 \leq \mu_{\text {prediksi }} \leq-0.7353
\end{aligned}
$$

Dari perhitungan diatas maka diketahui range nilai dari prediksi rasio $\mathrm{S} / \mathrm{N}$ sehingga untuk interval kepercayaan eksperimen konfirmasi jika memiliki nilai yang beririsan dengan nilai interval kepercayaan prediksi. Dengan demikian data bisa diterima.

\section{Eksperimen Konfirmasi}

Eksperimen konfirmasi dilakukan berdasarkan eksperimen yang telah dilakukan sebelumnya untuk membuktikan data tersebut sebagai penentuan kesimpulan. Eksperimen konfirmasi dilakukan sebanyak 5 kali pada kondisi optimal yaitu titik fokus sinar laser pada nilai $-14 \mathrm{~mm}$, tekanan gas cutting pada nilai 17 bar dan cutting speed pada nilai 0.6 $\mathrm{m} / \mathrm{menit}$. Untuk pengambilan data dilakukan sama seperti penelitian awal. Dan untuk perhitungan metode Taguchi hingga optimalisasi dengan Metode Grey relational analysis dilakukan dengan rumus yang sama. Sehingga hasil pengukuran masingmasing respon ditunjukkan pada Tabel 9.

Setelah didapatkan nilai dari hasil pengukuran, maka dilakukan pengolahan data seperti yang dilakukan pada sebelumnya yaitu dengan Persamaan $3,4,5,6,7$ dan 8 . Sehingga hasil pengolahan data ditunjukkan pada Tabel 10 dan Tabel 11 .

Tabel 9. Hasil Data Eksperimen Konfirmasi

\begin{tabular}{ccccc}
\hline \multirow{2}{*}{ Replikasi } & Sudut & Waktu & Laju Pemotongan & Kekasaran \\
\cline { 2 - 5 } & $\left(^{\circ}\right)$ & Detik & $\left(\mathrm{Y}_{1}\right)$ & $\left(\mathrm{Y}_{2}\right)$ \\
\hline 1 & 89.83 & 15.2 & $39.6988 \mathrm{~mm}^{3} /$ detik & $3.575 \mu \mathrm{m}$ \\
2 & 89.75 & 15 & $40.8553 \mathrm{~mm}^{3} /$ detik & $3.9125 \mu \mathrm{m}$ \\
3 & 89.917 & 14.8 & $38.0053 \mathrm{~mm}^{3} /$ detik & $3.3425 \mu \mathrm{m}$ \\
4 & 90.00 & 15.2 & $37.0837 \mathrm{~mm}^{3} /$ detik & $3.7300 \mu \mathrm{m}$ \\
5 & 89.5 & 14.7 & $43.9592 \mathrm{~mm}^{3} /$ detik & $3.6050 \mu \mathrm{m}$ \\
\hline
\end{tabular}


Tabel 10. Rasio S/N, Normalisasi Rasio S/N dan Deviasi

\begin{tabular}{ccccccc}
\hline \multirow{2}{*}{ Replikasi } & $\begin{array}{c}\text { MRR } \\
\left(\mathrm{Xo}_{(1)}\right)\end{array}$ & $\begin{array}{c}\text { Kekasaran } \\
\left(\mathrm{Xo}_{(2)}\right)\end{array}$ & $\begin{array}{c}\text { MRR } \\
\left(\mathrm{Xi}_{(1)}\right)\end{array}$ & $\begin{array}{c}\text { Kekasaran } \\
\left(\mathrm{Xi}_{(2)}\right)\end{array}$ & $\begin{array}{c}\text { MRR } \\
\left(\Delta \mathrm{oi}_{(1)}\right)\end{array}$ & $\begin{array}{c}\text { Kekasaran } \\
\left(\Delta \mathrm{oi}_{(1)}\right)\end{array}$ \\
\cline { 2 - 7 } & \multicolumn{2}{c}{$\mathrm{S} / \mathrm{N}$ Rasio $(\mathrm{Xo})$} & \multicolumn{2}{c}{ Normalisasi $(\mathrm{Xi})$} & \multicolumn{2}{c}{ Deviasi $(\Delta \mathrm{oi})$} \\
\hline 1 & 31.9756 & -11.0655 & 0.4007 & 0.5729 & 0.5993 & 0.4271 \\
2 & 32.2250 & -11.8491 & 0.5695 & 0.0000 & 0.4305 & 1.0000 \\
3 & 31.5969 & -10.4814 & 0.1443 & 1.0000 & 0.8557 & 0.0000 \\
4 & 31.3837 & -11.4342 & 0.0000 & 0.3034 & 1.0000 & 0.6966 \\
5 & 32.8610 & -11.1381 & 1.0000 & 0.5199 & 0.0000 & 0.4801 \\
\hline
\end{tabular}

Tabel 11. GRC dan GRG Eksperimen Konfirmasi

\begin{tabular}{ccccc}
\hline Replikasi & $\begin{array}{c}\text { MRR } \\
(\gamma 1(X o, X i)) \\
\text { GRC }(\gamma(X o, X i))\end{array}$ & $\begin{array}{c}\text { Kekasaran } \\
(\gamma 2(X o, X i))\end{array}$ & MRR & $\begin{array}{c}\text { Kekasaran } \\
\text { GRG }\left(\mathrm{Y}_{3}\right)\end{array}$ \\
\hline 1 & 0.4548 & 0.5393 & 0.1819 & 0.3236 \\
2 & 0.5373 & 0.3333 & 0.2149 & 0.2000 \\
3 & 0.3688 & 1.0000 & 0.1475 & 0.6000 \\
4 & 0.3333 & 0.4178 & 0.1333 & 0.2507 \\
5 & 1.0000 & 0.5101 & 0.4000 & 0.3061 \\
\hline \multicolumn{3}{c}{ Rata-Rata GRG } & 0.2155 & 0.3361 \\
\hline \multicolumn{3}{c}{ Total GRG } & \multicolumn{2}{c}{0.5516} \\
\hline
\end{tabular}

Hasil nilai total GRG eksperimen konfirmasi yang telah didapatkan digunakan sebagai nilai $\mu$ konfirmasi sebagai referensi nilai untuk perhitungan selanjutnya yaitu perhitungan interval kepercayaan eksperimen konfirmasi.

Interval Kepercayaan Ekperimen Konfirmasi

$$
\begin{aligned}
& C l= \pm \sqrt{F_{(0.05 ; i ; 4)} x M S_{e} x\left[\frac{1}{n_{\text {eff }}}+\frac{1}{r}\right]} \\
& = \pm \sqrt{7.71 \times 0 . .6870 x\left[\frac{1}{1}+\frac{1}{5}\right]} \\
& = \pm 2.5212
\end{aligned}
$$

Interval kepercayaan untuk eksperimen konfirmasi adalah :

$0.55-2.5212 \leq \mu$ konfirmasi $\leq 0.55+2.5212$

$-1.9696 \leq \mu$ konfirmasi $\leq 3.0728$

Perbandingan nilai interval kepercayaan eksperimen Taguchi dan nilai kepercayaan eksperimen konfirmasi ditunjukkan pada Gambar 9.

Untuk cara pembacaan Tabel 12 adalah pada eksperimen Taguchi memiliki prediksi -1.73 dengan optimasi berada dalam range \pm 0.99 dan pada eksperimen konfirmasi memiliki prediksi 0.55 dengan optimasi berada dalam range \pm 2.52 .

Tabel 12. Perbandingan Nilai Interval Kepercayaan

\begin{tabular}{lccc}
\hline $\begin{array}{l}\text { Respon } \begin{array}{l}\text { Laju Pemotongan dan } \\
\text { Kekasaran }\end{array} \\
\text { Prediksi }\end{array}$ & Optimasi \\
\hline $\begin{array}{l}\text { Eksperimen } \\
\text { Taguchi }\end{array}$ & Variabilitas & -1.73 & $-1.73 \pm$ \\
$\begin{array}{l}\text { Eksperimen } \\
\text { Konfirmasi }\end{array}$ & & & 0.99 \\
\hline
\end{tabular}

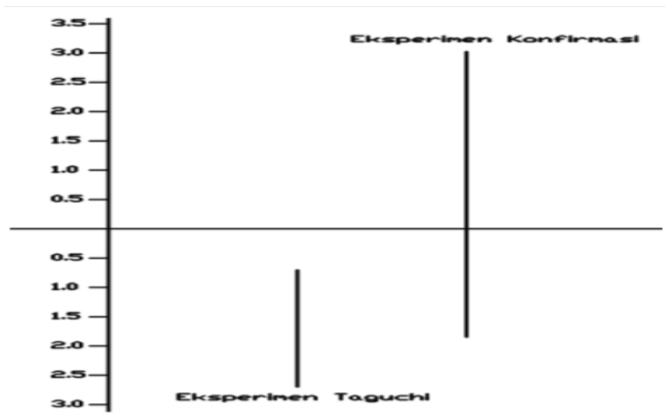

Gambar 9. Perbandingan Interval Kepercayaan

Berdasarkan pada hasil yang telah didapat pada eksperimen sebelumnya didapatkan bahwa kombinasi yang optimal terletak pada titik fokus sinar laser level 1 dengan nilai $-14 \mathrm{~mm}$ dan tekanan gas cutting level 3 dengan nilai 17 bar. Dengan menggunakan interval kepercayaan $95 \%$ maka interval kepercayaan eksperimen Taguchi beririsan nilai interval kepercayaan konfirmasi. Untuk perbandingan nilai interval kepercayaan ditunjukkan pada Tabel 12.

Berdasarkan perbandingan yang ditunjukkan pada Tabel 12 maka didapatkan nilai eksperimen Taguchi dan nilai eksperimen konfirmasi saling beririsan. Dengan demikian dapat diambil kesimpulan bahwa eksperimen dengan kombinasi level parameter $\mathrm{A}_{1} \mathrm{~B}_{3} \mathrm{C}_{1}$ adalah kombinasi level parameter yang tepat dalam mengoptimalkan respon kekasaran permukaan yang minimum dan respon laju pemotongan yang maksimum. Kombinasi level parameter tersebut adalah $\mathrm{A}_{1} \mathrm{~B}_{3} \mathrm{C}_{1}$, yaitu titik fokus sinar laser dengan nilai $-17 \mathrm{~mm}$, tekanan gas cutting dengan nilai 17 bar dan cutting speed dengan nilai 
$0.6 \mathrm{~m} /$ menit, dapat meningkatkan respon laju pemotongan dan nilai kekasaran permukaan pada proses pemotongan SUS 316L tebal $10 \mathrm{~mm}$ menggunakan mesin laser cutting.

Dapat disimpulkan dari perhitungan yang didapat sebelumnya bahwa konstribusi pada masingmasing parameter yang signifikan secara berurutan adalah parameter B (tekanan gas cutting) yang memiliki konstribusi terbesar dengan nilai persen kostribusi $50.3626 \%$ dan parameter A (titik fokus sinar laser) dengan nilai persen konstribusi 29.0119 $\%$ dalam mengurangi variasi dari respon kekasaran dan laju pemotongan. Sedangkan parameter C (cutting speed) tidak memiliki konstribusi yang signifikan dalam mengurangi variasi dari respon kekasaran dan laju pemotongan.

\section{Kesimpulan}

Pengaturan parameter yang tepat untuk titik fokus sinar laser, gas cutting dan cutting speed pada proses laser cutting untuk pemotongan SUS 316L sehingga dapat mengoptimalkan respon kekasaran yang minimum dan respon laju pemotongan yang maksimum adalah pada titik fokus sinar laser dengan nilai $-14 \mathrm{~mm}$, tekanan gas cutting dengan nilai 17 bar dan cutting speed dengan nilai $0.6 \mathrm{~m} / \mathrm{min}$.

Parameter titik fokus sinar laser, tekanan gas cutting dan cutting speed memiliki konstribusi dalam mengurangi variasi dari respon kekasaran dan laju pemotongan yaitu untuk titik fokus sinar laser memiliki konstribusi $29.01 \%$ dan tekanan gas cutting memiliki konstribusi paling besar dengan 50.36\%. Sedangkan cutting speed tidak memiliki konstribusi yang signifikan dalam mengurangi variasi dari respon kekasaran dan laju pemotongan.

\section{Daftar Pustaka}

Akhyar, G., Che Haron, C.H., Ghani, J.A., 2008, Application of Taguchi Method in Optimization of Turning Parameters for Surface Roughness, International Journal of Science Engineering and Technology, Vol. 1, No. 3, pp 60-66.

Anonimous.(2010).Operator Manual Laser Cutting.TRUMPF, Jerman.

Anonimous.(2010). TruLaser 3030 Lean Edition.TRUMPF, Jerman.

Black, J.T. dan Kohser, R.A. (2003). Degarmo's Materials and Processes in Manufacturing.John Wiley and sons Inc., Hoboken.

Belavendram, Niccolo, 1995, Quality By Design

Hazim, F. (2005).Pengaruh Tekanan Gas Potong dan Diameter Nosel terhadap Kekasaran Permukaan, Tebal Slag dan Lebar Kerf pada Baja JIS G 3101 SS 400 dengan Laser Cutting. Jurusan Mesin Fakultas Teknik,Universitas Muhammadiyah Malang, Malang.
Hidayat, (2012). Penerapan optimasi multirespon menggunakan hybrid principal component analysis-taguchi pada proses turning material polyacetal, Proceeding, SNTI III-2012 Universitas Trisakti

Jamal, K., Jain, A., dan Grover, S. (2010).Optimization of multiple-machining characteristics in wire electrical discharge machining of punching die using Grey relational analysis.Journal of Scientific and Industrial Research, Vol 69, pp606-612.

Juhana, O. dan Suratman, M.(2000).Menggambar Teknik Mesin dengan Standar ISO. Pustaka Grafika, Bandung.

Lu, H. S., Chen, J. Y., dan Chung, Ch. T. (2008). The optimal cutting parameter design of rough cutting process in side milling.Journal of Achievements in Materials and Manufacturing Engineering, Vol 29.

Muliyanah, D.(2011).Optimasi Kualitas Garitan dengan Rancangan Kuat dari Eksperimen selama ND: YAG Laser Cutting Lembaran Paduan Aluminium Tipis untuk Profil Straight.Jurusan Teknik Industri Fakultas Teknik.Universitas Sultan Ageng Tirtayasa Banten.Cilegon.

Rochim, T.(2001). Proses Pemesinan. Institut Teknologi Bandung. Bandung.

Rosiawan, M., Alvina, B.A., Hadiyat, M.A., 2011, Optimisasi Parameter Vertical Injection Molding Menggunakan Metode Taguchi Untuk Data Prosentase Cacat, Prosiding $6^{\text {th }}$ National Industrial Engineering Conference, Teknik Industri Universitas Surabaya.

Sato, G. Takeshi dan N. Sugiarto H. (1994). Kekasaran Permukaan Pada Material. Graha Ilmu. Yogyakarta

Shivapragash, B., Chandrasekaran, K., Parthasarathy, C. dan Samuel, M. (2013). Multiple response optimizations in drilling using Taguchi and Grey relational analysis. International Journal of Modern Engineering Research, Vol 3, pp $765-768$.

Soejanto, I.(2009). Desain Eksperimen dengan Metode Taguchi. Graha Ilmu. Yogyakarta.

Park, S., H., (1996). Robust Design And Analysis For Quality Engineering. Champman And Hall. London.

Purwanti, E. P. dan Pilarian, F.(2012). Optimasi Parameter Proses pemotongan Stainless Steel SUS 304 untuk Kekasaran Permukaan dengan Metode Response Surface. Politeknik Perkapalan Negeri Surabaya. Surabaya. 